\title{
Cultural determinants in Chile - the land of great ambitions
}

\begin{abstract}
Chile is commonly described as "the best student" in the Latin America class. In 1985 Harrsion with his publication Underdevelopment is a state of mind [Lawrence, 1985] started research on the significance of cultural determinants in economic development. Having based his research on two examples, he proved his thesis that culture is a determining obstacle in the development of Latin American states. Causing many discussions, he initiated a wide range of socio-economic research, the aim of which was to present to what degree and what kind of cultural factors shape political and economic development, and which ones lead to social stagnation. Further research by Harisson and Huntington which was published in their work Culture matters [Lawrence, 2000] presented a wide spectrum of interconnections of culture with civilization development, institutions and geographic conditions. The scientific discourse includes the phenomenon of cultural changes promotion as an element of the pro-development policy as well as anthropological considerations on the influence of "cultural imperialism" of Europe and the States in the globalization era on the preservation of societies' cultural identity. Many publications in the area of research on cultural conditions in management and negotiations appeared in the 1990s. This scientific discourse has gathered its own momentum as the amount of research brings about the increase of connections of interdisciplinary cultural determinants.
\end{abstract}

Key-words: Cultural determinants, Chile

The concept of culture is closely related to the concept of society despite various methodological approaches and a plethora of definitions which have been formulated. Culture is a relatively integrated whole including human behavior which is shaped according to the patterns dominant in a given community, which have been formed and learned through interactions; culture also covers the results of such behaviors [Kłoskowska, 1980, p. 40]. 


\section{Dorota Bochniak-Piasecka}

This definition includes all aspects of social life, such as: values, attitudes, convictions, opinions and foundational beliefs which are common among the members of a given community and which are expressed by their practice, symbols, institutions and interpersonal relationships. This universal definition which is popular in social science constitutes the basis for specialized or synthesis-oriented research and scientific considerations. Linton defines culture from a psychological perspective as "organized, repetitive reactions of society members" and he stresses that culture refers to the whole life of a given society and not only to those parts which are regarded as superior or more desired [Linton' 2000, p. 151]. We can develop this idea and say that there is no society without culture and, consequently, that "it is the culture which identifies man regardless where he was born" [Hofstede, 2000, p. 40]. Hofstede argues that culture is acquired during upbringing and that it is "collective mind programming" which differentiates one group from the other [Hofstede, 2000, p. 41]. "Transfer and acceptance of certain cultural patterns is subject to the norms and aims which are socially recognized" [Kłoskowska, 1980, p.51]. In order to form separate national culture one needs common historic experience during which socially accepted behaviors are shaped through selection. "Awareness of commonly accepted values and norms gives the feeling of safety and stability" [[Kłoskowska, 1980].

Concepts of national culture identify conscious and unconscious strata and levels, i.e. those functioning in the subconscious. In the consciousness we can find visible and functional elements, such as language, clothes, architecture, music, literature, cuisine, behavior. Subconsciously coded culture elements are not visible at first sight and result from basic values and norms which are present in a given society, such as: equality, individual, cooperation, work, attitude to authority and law, social status, attitude to etiquette, customs and habits, religion, emotionality, attitude to time and its organization, past, present or future orientation, meaning of gestures and symbols [See: HampdenTurner, Trompenaars, 2002, p. 37]. Authors of Seven Cultures of Capitalism Fons Trompenaars and Charles Hampden-Turner created a clear model of cultural values dilemmas which helped to analyze and describe the cultures of such states as France, the United States or Japan. This model is based on the necessity of selection and simultaneously of reconciling basic values which are present in every society regardless of its degree of economic or civilization development. In all countries people's attitude to legal and ethical regulations is determined by human relationships and resulting obligations, which is reflected by universal or particular attitudes or behaviors. In a given society pro-transaction or pro-partnership behaviors may dominate to a various degree (10 Gesteland). In the actions of state or individuals we can find activities and 
reasoning based on analysis or synthesis. Collective or individual attitudes may dominate with external or internal control. Defining social status on the basis of individual achievements or ascribing a higher status which is correlated to hierarchical social structure presents a dilemma between equality and hierarchy. Understanding of time and how it is used was identified by researchers as the dilemma between linear and synchronic actions. In interpersonal relations one must not omit the difference between emotional expressions in various nations, which we experience in direct contacts asduring the first meeting we encounter either lively emotional outburst or bigger or smaller emotional reserve. This model of values dilemmas and the consequent attitudes and behaviors help us to learn and understand a given culture better, to become aware of cultural differences between our own system and our expectations towards the people of different nationalities regarding how they should think and act.

Here we can encounter the dilemma of assessing or not assessing a culture. Scientific research development would be impossible without comparing cultures, without categorizing value systems and cultural behaviors. Collating cultural values and behaviors, their comparative analysis has brought about the creation of cultural differences models as an effective tool which is used not only in research but mainly in management, negotiations, business, diplomacy or tourism. The aim of this research is to facilitate fast communication between the parties coming from different cultures, where behaviors and interpersonal forms are naturally diverse despite the common cultural area they originate from (e.g. European and Arab countries).

Latin American countries are often perceived from the ethnocentric European perspective as culturally identical, due to a common language (apart from Brazil) and history of the conquest. At the turn of the $18^{\text {th }}$ and $19^{\text {th }}$ century independence movements reached also Latin America, which led to the formation of independent states. It is worth (even concisely) reminding some basic historical facts which are the basis of the Chilean cultural identity.

The independent Republic of Chile was created 200 years ago and in 1833 she accepted the centralized constitution which became the foundation of a stable state with modern taxation and legislation systems, efficient administration and strong army (it happened thanks to a minister Diego Portales). Por la razon or la fuerza - by reason or by force - this slogan accompanied the formation of the independent state of Chile. At that time European civilization had been flourishing there for over two hundred years due to Jesuits who brought from Europe craftsmen, architects, painters, sculptors, weavers, pharmacists. This brought about the development of science, creation of the largest library (over twenty thousand books) in Latin America. The influx of aristocracy and gentry resulted in the formation of strong elites. Supporting immigration from 
Europe, mainly from Germany, England and France, led to the development of trade, fleet and sea transportation and creation of profitable land properties in the south of the country where the climate resembles the one in Central Europe. During the next decades Chile became the strongest state in the Andes region, developing strong free market economy which is based on extractive and processing industries (charges for saltpeter export constituted a half of budget revenues, now charges for copper, molybdenum and other metals extractions cover half of the state budget). In the $20^{\text {th }}$ century the world wars and financial crises put an end to Chilean economic prosperity and directed positive social emotions (mainly of the educated and of ruling classes) towards communist ideologies. This brought about the victory of Salvador Allende in the presidential election, who was a left-wing candidate. His government nationalized copper industry (up till now the biggest mine Chuquicamata is owned by the state), banking, processing sector, introduced agricultural reform, control over international trade. Those reforms undermined mainly free-market structures and consequently the interests of oligarchy and ruling elites and led to total market disorganization. Old Chileans, who remember those times, talk about empty shops, lack of food and huge inflation. Total disorganization and external pressure (mainly from the USA) created the conditions for the military coup in 1973 after which the military junta took over. The period of authoritarian government by Pinochet has two faces. The first one has an economic dimension - introduction of a free-market model according to the Chicago school doctrine resulted in a fast GDP increase (7\% in 1985-88, 10\% - in 1989 and 6.5\% in 2010); the other face has a human dimension - thousands of victims of military terror who were arrested, killed or in the best case forced to emigrate. The military junta governments divided the Chilean society, which is evidenced by every free election (since the return to democracy in 1989) - electoral votes spread evenly into the left- and rightwing parties. Distribution of votes analysis according to social strata, place of living (big cities - countryside, north-south-center) shows a relation between the income level, social hierarchy place and political orientation - owners clearly display pro-Pinochet tendencies.

Economic restructuring forced the society to adapt to the free-market system. In the 1990s, after Pinochet had stepped down, the issues of great social inequalities and poverty boomeranged, taxes were raised and new social benefits were introduced. Every subsequent President faces social problems which stem from the neo-liberal system which had been effectively introduced. Democratic changes almost have not affected property distribution and political influence. In the ranking of states with the greatest social inequalities (according to Gini coefficient - the income inequality scale) Chile occupies the fifteenth place, 
the situation is worse in Colombia, Bolivia, Brazil, Guatemala and Paraguay, however there are smaller inequalities in Peru and Mexico, while Uruguay and Ecuador occupy the thirty-third and thirty-fourth position respectively. (The countries with the biggest inequalities are the ones where a small group obtains most of the national income, it means that the higher position on the scale, the biggest the gap between a small elite and the remaining part of the population. The mother of Latin America - Spain - occupies the $103^{\text {rd }}$ position, while Sweden can boast of the smallest inequalities, with her last place in the ranking).

What does an average Chilean look like? Their physiognomy is the evidence of the various origins, which results from many centuries of mixing between many European nationalities and Indian tribes. Characteristic appearance covers slightly slanted eyes, wide nose, dark rather straight hair, round face,. They are short (women often have corpulent figures) and dark-skinned. Population appearance changes together with the latitude; we must remember that Chile stretches from the Atacama desert (Indian territories, the Incas state influence, mining area) to the fertile Central Valley (vineyards, orchards, gardening) with beautiful land properties belonging to the Chileans whose ancestors came from Spain, Italy and France, to the Great Lakes - the Mapuche area, which in the 1850s was given to thirty thousand German settlers, who turned forest into arable land and built cities, developing processing industry, to cold Patagonia with sheep and stock-raising ranches which is settled mainly by the Croatians and Swiss. The coastline of four thousand kilometers was the territory of British settlement who contributed a lot into the organization of navy and the creation of shipbuilding industry, harbors, roads, etc. We must not omit the capital - Santiago - where almost half of the country population live and work (7,200,000 people out of. $17,248,614$ citizens according to the latest census of 2011); it is also an academic center forming intellectual and political elites since the beginning of the independent state. Over $87 \%$ of the population live in the cities where the elites and middle class are formed. Sightseeing Santiago, one is struck by changes in the appearance and physiognomy of the people who live in different parts of the city. The richer the neighborhood, the taller the people are and they do not differ from the Europeans. In poor districts in Santiago, in small towns and in the countryside we will have no doubts that we are in Latin America (apart from the cold South - Patagonia). Even outside touristy places we can face curiosity of the people who are not used to being visited by someone from the higher class.

In Chile we can encounter communities which take care to preserve the national identities of their ancestors, such as Chileans of Jewish origin and Palestinian Catholics. Each of those national groups contributed the values and attitudes necessary to shape the Chilean cultural identity. 
According to the Chilean sources $65 \%$ of the population has European and native origins, while $25 \%$ is of the European origin (mainly Spanish, German, Croatian, Italian, French and their combinations). Indigenous Indian population are mainly the Mapuche and Araucanian Indians who constitute $6 \%$ of the total Chilean population. In another research from $64 \%$ to $90 \%$ of the population declare that they belong to the white race despite the encyclopedic data claiming that $52,7 \%$ of the population are white, while $44 \%$ are Mestizo. Only 3,2\% were regarded as the natives (census of 2002).

The name Mestizo is not used in Chile because everyone would rather present their European origins, placing themselves higher in the social hierarchy (in the $16^{\text {th }}$ century the conquistadores came there without their women, hence such a big mix of European and Indian blood). It should be mentioned that in Chile, unlike in Argentina, there has never been any ethnic cleansing (apart from Patagonia where the border between Argentina and Chile was changed). In the report written by the Ideas Foundation in 1997 28\% of the respondents thought that their country is more advanced in many areas as compared to other Latin American countries because there is not any African population (which is not true from the historical perspective as the African slaves were brought to Arica on the border with Peru, but most men were killed during the war for the Pacific in 1879-1894). In fact there has never been any huge Japanese or Chinese migrations. In the recent years many Pakistanis have come there and they deal mainly with trade in duty-free zones (Arica, Iquique, Punta Arenas).

The research conducted by the Ideas Foundation shows that average Chileans are brunet but are convinced that their hair and complexion is fair that that they belong to a white race. Only 27\% of the respondents declared the Mestizo origins. Consequently it means that the Chilean are hardly ever proud of racial mix in their blood and are very sensitive regarding their aspiration to belong to a white race.

In 1993 the Chilean Parliament passed the Indigenous People Law recognizing Indians as the descendants of the peoples living on the territory of Chile since the pre-columbian times and having the right to manifest their ethnic and cultural origins and the right to the land they occupy. The most important ethnic groups include: Mapuche, Aymara, Rapa Nui from Easter Island, Atacamenos, Ouechuas, however the only culturally strong and significant group are Mapuche. In the last 15 years the government has undertaken many social and economic initiatives in order to promote the native peoples' situation but they are not sufficient. An average Indian family lives on the level which is much lower that the national average: only $58 \%$ have running water and $65 \%$ are not covered by electricity network. The issue of land ownership and compensation has not been fully regulated as they are in 
the hands of private owners (the UN report of November 2003). In the last three years (2009-2012) to celebrate the two hundredth anniversary of Chile there was an exhibition devoted to the Mapuche culture in the Cultural Centre in la Moneda (Presidential Palace); it which was later sent to Europe. Although the state attitude towards the Indians has completely changed, in the Chilean mentality they still remain on the lowest level of the social hierarchy, which is mostly determined by their place of living and low education. During our three-year stay in Chile, meeting hundreds of people who were engaged in the politics, we encountered only one Mapuche who was well educated in Great Britain and was an office worker in the Regional Office in Coyhaique. It can be easily observed that the Chileans form a class society.

\section{Social promotion determinants in Chile, hierarchy and status dilemma}

All societies have worked out in their cultures how to grant higher status to certain members, showing thus that their actions deserve special merit. In some societies such "elevation" is given to people for their achievements and work contribution, in other words it refers to "what one does". In other societies it refers to "who one is". In this case the criteria of granting higher status are historically shaped and there can be many of them, e.g. sex, race, social background, connections, age, education, profession, property, etc.

\section{Attributes of ascribed status}

A Chilean scientist Oscar Contardo in his book Siutico presents the phenomenon of common and historically determined Chilean mentality problems related to the ascription of big significance to social status and hierarchy. In the turn of the $19^{\text {th }}$ and $20^{\text {th }}$ centuries the concept of arribisimo being superior - became very popular and was based on negating one's origins, pretending to be richer and using various attributes to achieve that. We can find many examples in the Chilean version of Spanish language Chilenisimo which was used by the middle class and which up till now distinguishes Chile from other Spanish-speaking cultures. The elites, however, manifest their superiority trying to speak Castilian Spanish: the nicest complement is to say that one has a Castilian accent. The Chilean custom of tomar onces, i.e. of afternoon snack, has survived only in a deep countryside as it was seen as a definite sign of lower status. Siuticos, i.e. the people who aspired to climb to the higher social level in the social hierarchy, had afternoon tea - five o'clock.

The rich have always tried to live according to European patterns and their economic status allowed them to create the desired image. Among plutocracy people tried to speak French, they had to go on a short trip to France - up till now French language places a person in a good position in their social environment. Since the beginning good knowledge of Spanish, French and 
English has determined if one belongs to the elites or not. Even today the Chileans assess the person they have just met on the basis of their knowledge of foreign languages. It can be noticed that the development of this type of attitude towards social hierarchy was grounded on the experience where in fact the state and national identity were shaped by immigrants from Europe: on one hand - big land owners and the Church and on the other - national and other heroes, such as Carter brothers, O’Higgins, Manuel Rodriguez or San Martin, and thirdly - intellectual elites and liberals. All those facts demonstrate the significance that the Chileans attach to origins and social status.

The Chilean research conducted in 2006 demonstrated that over half of the employers attach greater significance to a candidate's origin than his education. Between business, political and intellectual elites there have been historical interconnections. In 1989 in the Parliament which was democratically elected after sixteen years of military regime there were many relatives of historical and contemporary leaders. Belonging to an influential family, who has for generations directly or behind the scenes participated in governing the country, having a known and respected surname is in Chile the best recommendation, a guarantee competence and trust. Social background and consequently education acquired in the best schools are the basis for the status ascribed in Chile. For the European the value of education is obvious and is not determined by the family's wealth because education is free (apart from the UK where one pays for studies) and depends on intelligence, talent and hard work.

Education in Chile is based on two pillars: of the private and state sectors, hence in the beginning children are segregated according to the material status of their families. Sending children to a good private school is an investment in their future, in order to get to one they must go to a private kindergarten, often belonging to this school. In Santiago enrolling children to private schools or kindergartens must be done a year in advance. And the main issue here is not better results (public schools often have better results) but belonging to a higher social group at the very start. The foundation of this type of behavior is the desire to succeed in life on the basis of historical social understanding of hierarchy and equality.

Foreigners encounter the same type of problems if they want to enroll their child in a private school; if in their country he did not attend a private school, no renowned school in Santiago will accept him. Here we are faced with cultural crash; the Chileans do not understand why the child of parents who have significant professional positions attends a public school, which is a standard in the European states and in the US. (The only elitists school which works according to the European school year timetable September - June and not March - December, where classes are held in English, has the highest school fee of about twenty-five thousand dollars a year). 
From the conversations with the Chileans I learned that during a job interview an employer asks what schools the candidate attended, starting from the primary school and finishing with the diploma of the most prestigious university, because this is the most important determinant of his social position, not his competence, knowledge or talent. During the first meeting one is evaluated according to common criteria of European appearance - the taller the person, the fairer his complexion and hair, the better the first impression is. A place of living is another important criterion: a good Santiago neighborhood, near the business center at El Golf, Las Condes and first of all a residence area of Vitacura with the embassies and residencies. The old Providencia centre is slowly becoming a historical place with state offices, museums, universities and state institutions. La Reina and Nunoa are inhabited by the professionals and intellectuals. Working class lives in the south and west suburbs. Most of the elite representatives were educated in the same private schools, the same universities, lived nearby. A place of living is then a good guarantee of success at work or in business. Taking into account this important criterion for belonging to an upper social stratum, young people at the beginning of their professional career often take loans for very expensive apartments in those districts in order to place themselves and their families on a good position. Many foreigners or the Chileans who come from other places and who start work in international corporations submit to this unwritten rule. Social promotion or confirmation of a social status takes place through the migration within the city. Of course those types of behavior concern only the upper and middle classes because young people from lower social classes (baja) have no chance to study in a renowned school, not only due to financial but also cultural reasons. In our conversations the conservatives often stress that it is impossible to maintain close contacts or to mix with lower strata not because of big income differences but because of low culture. Language errors, bad manners, wrong clothes, lack of etiquette socially disqualifies them.

"Ascribed" status which determines who you are dominates in the Chilean society not only professionally but also socially. Membership in recreational sport or business clubs where subsequent social groups are formed creates your position. No one from the upper class would dare to criticize publically a high price of service or goods. A thousand dollars paid for a night in the Explora hotel in Torres del Paine or Easter Island guarantees the quality of services and the wealth of the company. Healthcare is also divided into two sectors; using private medical services in the most expensive clinics also determines if one belongs to a significant group. This sense of belonging is manifested every day. All the newspapers, starting with influential El Mercurio and finishing with the smallest local ones have social chronicles with photos of important people who 


\section{Dorota Bochniak-Piasecka}

participate in current economic, business, scientific, cultural and other events. Photos in Vida Social confirm belonging to the elite. In the Chilean mentality there is a famous saying that if you cannot show something it means that you have not done it. Chilean aspirations to get to the highest position even within one social strata are visible every day

\section{Female and male status in Chile}

Sex is an important category in the Chilean social hierarchy although women and men are legally equal pursuant to the Constitution and women were granted voting rights in 1949 due to Maria de la Cruz's dynamic activity and her Women's Party. Historically determined model of a Chilean family is based on machismo, i.e. on man's dominance and results from imbalance in sex structure - there were more men than women. Because of distant working places (Atacama mines) and difficult living conditions mainly men were employed. However with time good salaries and better social conditions brought about development of cities in mining regions, such as Iquique, Calama. The social model was dominated by man who up till now are regarded as unfaithful and egocentric machistas. Family violence, bullying and rapes occurred every day. The permission to rule over women and a sense of ownership were so strong that they often resulted in murders (Historia de la vida privada en Chile, p .97 ). In Latin America we often encounter murdering women, the so called femicidio, in Chile there were fifty cases of women killed by their husbands.

In 2011 after a mining accident in San Jose miners were trapped 700 meters underground. During a rescue action which lasted 69 days three times more wives came to the employers requesting their salaries than there were men. It turned out that they were in fact in live-in relationships with those men and that they had children together. It became clear that this phenomenon was caused by very restrictive law which did not allow divorces. A Chilean often has two or three women, not wives or partners but mujeres (this is a colloquial name). For generations there has been a custom of having two families - one with a lawful wife and the other with a lover. There have never been any conflicts as this issue is very discreet; there is a Chilean saying: Don't be stupid and don't tell anyone about it. Statistical data of 2012 show that during one year only $3.3 \%$ people out of one thousand get married; fifty years earlier this indicator was $7.3 \%$. One can clearly observe a tendency towards preference of informal relationship, which can be fast and easily changed. As the consequence, $60 \%$ of children are born out of wedlock. After interviews in various environments we can claim that this custom does not apply only to the lowest class, but it is also characteristic of the middle and upper classes - having children from different relationships is becoming common. In El Mercurio of 9 June 2012 in the article "How has Chile changed in the last fifty years" statistical data show 
a fast growth from $18.8 \%$ to $35 \%$ of households where women alone run the household and raise children.

A declaration of entry to Chile contains entries: single, married, widow. Female status depends on that of a man: father, husband or former husband. Protection of a woman and her rights has always been provided by her family of origin. In order to protect maidens and single women from a dangerous male world (extramarital relationships, unwanted pregnancies, etc.) they were isolated from the environment. It went to such extreme that young women with better family backgrounds were kept in special rooms and surrounded with constant care. Even then a gap between the middle and lower class was created. A contemporary middle class custom of surrounding a fiancé with constant care and surveillance dates back to those times (pololo). He informally becomes a member of his fiancée's family and is in fact financially supported by them.

In a traditional Chilean upper and middle class family women did not work professionally. An average number of children was 4-8 and this required maternal presence at home with a daily and nannies. In 1962 an average mother had 5.4 children while fifty years later -1.9 children despite a binding antiabortion law. The Chilean healthcare, however, gave supremacy to mother's health and not to keeping a fetus. A contemporary Chilean family cannot imagine how a household can be organized without servants. A number of servants is the proof of one's wealth but primarily of belonging to the middle and upper class. Sex equality in the European sense is not understood and recognized mostly by men who demonstrate that they must be waited on in everyday life, e.g. a Chilean will not accept self-service even during a buffet party. Men manifest their cultural supremacy in all spheres of life, e.g. at work, in a shop, in traffic, etc.

Presently one can observe the tendency to increase professional activity of women and their status in the society through, for example appointing them to state positions (regional governors or ministers) by President Pinero. Despite those efforts in 2012 female participation in the public state life amounts to $13 \%$ while this indicator for Latin America is $23 \%$. It is misleading to observe this externally through the female presidents in Argentina or a previous term of office of Michelle Bachelet in Chile. Unlike in Argentina, the election system in Chile is modeled after the American one, the president who is elected in direct elections has full executive power, forms the government and nominates all state posts, but he can govern for only one term of office. More and more women get education in the areas which used to be reserved only for men, such as engineering and medicine. In 2010, 7109 women graduated from the Police School for Officers and they are currently working in police: in prevention and family protection, event safety protection, in the guard of the President Palace La Moneda and in Special Forces. Women in cities are often influential and active in cultural, social and scientific areas. 


\section{Dorota Bochniak-Piasecka}

Chile is the country with a strong influence of the Roman Catholic Church, $70 \%$ of the population declare to be Catholic and divorces were legalized only in 2006. Family is a value in itself and the Chileans argue that it is an economic unity. After marriage a husband has an obligation to take over his wife's property and to represent her financial interests before the law (for example during acquisition the right to estate after grandparents or parents). Of course prenuptial agreements are possible. The law also protects children; a child cannot leave Chile without the parents' agreement which is certified by a notary even in case of a common trip. A model of a traditional multigenerational family who live together has not survived physically particularly in cities where $87 \%$ of the population live. However, it is still realized by fulfilling obligations and nourishing relationships. During Pinochet government Opus Dei movement, which was started by Josemaría Escrivá de Balaguer in 1928 in Spain, developed fast; the founder visited Chile in 1974. For the last thirty years this organization has been directly submitted to the Pope, and in 2002 father Escriva was canonized. Identity of lay members is not revealed. The main objective of the organization is to achieve social harmony through individual awareness of one's role. Good work is the highest value and it can be only reached through obedience, discipline and respect for hierarchy. Man should live in his own environment, where he was born and fulfill his duties the best he can. Conscientious work is the biggest value which sanctifies everyday life. In the companies run by its lay members such qualities as trust, loyalty, business ethics are more important than fast profits. In Chile this organization attracts the extreme right, the richest people in the country, businessmen, lawyers with wide connections in the business world. Despite accusations of sectarianism and extreme conservatism the strength of Opus Dei flows from the combination of political power and money. The organization affirms the idea that "capitalism was revealed by God". Neoliberal doctrine was soon adapted by plutocracy to business development and to leading the state out of the economic crisis.

The Chileans' rigid attachment to ascribed social status has strong and deep roots going down not only into history but also into religion. Broadly understood family (origins and connections), age, sex, appearance, friends, place of living, work and educational background - all those categories intertwine and determine individual life path. Marriages are contracts between the young coming from the same social class and their families. In this country Cinderella story does not come true.

Social origin is the basic determinant, jumping on a higher level of the social ladder is very difficult for the Chilean both from the middle to the upper class and from the lower to the middle class. American careers similar to Bill Gate's or Zuckermen's do not happen in Chile. An emigrant from Europe may become 
a millionaire but not a student from a poor school coming from a working class family. Newcomers from Europe are assessed according to the same criteria. Single young women even with higher education have a chance to obtain a good position only when they come as specialists with a previously signed contract.

\section{Social promotion and education}

Social promotion in Chile through education is not easy and generally impossible for the poorest social stratum which constitutes $20 \%$ of the population. In 2002 the government developed the National Policy and Action Plan for Children and Youth and started Chile Solidario Plan. For the first time a family became the policy focus with the UNICEF support. In order to raise education level the amount of lessons was increased and education became obligatory to the age of 12 instead of 9 . The education criterion of good social status is a financial burden even for a middle class because one pays for all higher education schools both private and state-owned, while a school fee, depending on the major, varies from 400 to1000 US dollars monthly. The main slogan of long student demonstrations in 2011 was "free education". This rebellion expresses objection against social inequalities, lack of effective social promotion path and also inability to maintain one's position which has been obtained through education by the middle class and the not-so -well -off youth. Often the whole broadly understood family (grandparents, aunts, uncles, etc.) of a student takes a loan to cover the costs of his studies. It may seem that payment for three-year bachelor degree studies should not cause such riots. In fact the next obstacle is a credit system at schools which forces students to repeat the whole year if they do not get a credit from only one subject, which prolongs the whole studying (and paying) period to five and sometimes even eight years. Consequently about $50 \%$ of students drop off, as they cannot afford to repeat and continue their studies despite the high costs they had already borne. Of course education in technical or medical schools lasts two or three years longer. Despite those difficulties the total number of students in 2011 was 602,429 people which constitutes $3.6 \%$ of the whole population. In comparison to 27,323 people in 1962 ( $0.3 \%$ of the population) one can observe a hundredfold growth. It should be noted that regular full-time daily studies are the only available type of studies. A fresh graduate is obliged to do internship in the place assigned by the state office, mostly in the countryside. A younger generation willingly affirms the European model in order to experience the benefits of social promotion in return for their hard work at university. In their social contacts they prefer those who are not family. The basis for this type of behavior is the desire to succeed in life. The Chileans are obedient to their parents and respect the elderly so their rebellion is limited to youth. Historical social 
determinants, understanding of hierarchy and equality imposes opportunistic behaviors and submission to the existing model.

\section{Equal before the law or how do the Chileans solve the hierarchy - equality dilemma?}

In a democratic state there must exist determined and accepted hierarchy boundaries which protect law and order. On the way from the airport you can observe a strict adherence to the right of way regulations in traffic. You must not change the lane until all the cars pass you, you can block the traffic on the lane where you are waiting but no one will let you in. You can try to squeeze in but in this case you may have an at-fault accident. Every day this situation causes long traffic jams during rush hour and prolongs the commuting time. But the law remains the law. The Chileans respect the law without exceptions. The same regulations are binding for everyone. Any attempt to corrupt the police will fail because you have go to the court for a traffic offence. The police is militarized and do not accept bribes despite their low salaries as the state provides all social security benefits, including holiday trips abroad. Civil servants have several times higher salaries than an average remuneration. The Anticorruption Act is not ineffective as informing is treated as a civil duty. Even at work if you neglect to do your tasks, your colleagues will inform the supervisor about this.

In the world corruption perception rankings the majority of Latin American countries occupy very low positions. In 2011 Transparency International classified 183 states,. The research was based not only only on corruption but on its presence in sociallife: citizens were asked if, how often and in what situations they have to give bribes. It is difficult to assess corruption itself as it is illegal and secret. Three independent surveys were used for this ranking. The top of this list is for the "cleanest" countries, such as New Zealand, Denmark, Finland. Chile occupies the $22^{\text {nd }}$ position. Together with Uruguay she is a praiseworthy exception. To compare: 24 - USA, 41- Poland, 100 - Mexico, Argentina, 120 Ecuador, Guatemala, 143 - Russia, Belarus.

In the last decades the law has played the most important role in the government politics. After the period of chaos and big corruption there came the time of military terror and conscientious implementation of the Chicago Boys' neoliberal philosophy. Chile was the first country where they tested a new economic model of open economy with low salaries and drastic cuts of expenditure in the public sphere. This period of economic prosperity is well guarded by the state. Every Act which is presented in the Parliament must present the costs of its implementation and sources of finance. For example we asked why there was no waste segregation and there is no appropriate Act. The answer was that passing this Act made sense only when there were: education about waste, waste disposal and waste processing plants, estimated costs of its 
introduction, financing subject and certainty that this amount of money would be provided. Passing the law without the possibility to implement it, the law which has no chance to be executed is a nonsense in Chile.

\section{Literature:}

Harrison, L.E., Underdevelopment Is a State of Mind. (Cambridge: Center for International Affairs, Harvard University; Lanham: Md; Uninersity Press of Americz.1985.

Harrisom, L. E. Hungtington, Samuel, P.Culture Matters. First published in the United States by Basic Books, a Subsidiary of Perseus Books L.L.C. 2000.

Hofstede, G. Kultury i organizacje. PWE.Warszawa: 2000.

Hampden-Turner, Ch., Trompenaars, A. Siedem Wymiarów Kultury. Oficyna Ekonomiczna. Kraków: 2002.

Kłoskowska, A. Kultura masowa. PWN. Warszawa:1980.

Lewis R.D. When cultures Collide. NB. London: 2005.

Linton R. Kulturowe podstawy osobowości. PWN. Warszawa: 2000. 